\title{
THE YEAR 1964 IN THE HISTORY OF ESTONIAN ANTHROPOLOGY
}

\author{
JaAn Kasmel, Tiiu Kasmel \\ Centre for Physical Anthropology, University of Tartu, Tartu, Estonia
}

The first data on the everyday life and descriptions and assessments of the appearance and body build of one or another nation or inhabitants (men, women, children) of a geographical region can be found in the writings of early travellers and explorers.

The first such characterisations of Estonians date from the second half of the 18 th century.

In the introduction to his monograph on Estonian men's anthropology printed in Tartu in 1964, Prof. Juhan Aul wrote that in that year 150 years had passed from the publication of the first anthropological study of Estonians.

This was the doctoral thesis of Karl Ernst von Baer, a graduate of the Imperial University of Dorpat (the present University of Tartu), defended on 29 August 1814 (10 September New Style) [5] On Estonians' Endemic Diseases (Figure 1). He was the first to give more detailed descriptions and assessments of Estonians' (men's, women's and children's) body build and appearance than before. K. E. von Baer's doctoral thesis was the first step on his long and fruitful path as a scientist, and it also marked the beginning of the anthropological research of Estonians.

Prof. J. Aul's monograph was thus dedicated to the 150th anniversary of the defence of K. E. von Baer's doctoral thesis as well as to the beginning of Estonians' anthropological research [16].

This year, however, we can celebrate the 200th anniversary of the defence of K. E. von Baer's doctoral thesis and the beginning of Estonians' anthropological research and the 50th anniversary of publication of J. Aul's monograph on Estonian men's anthropology (Figure 2). 


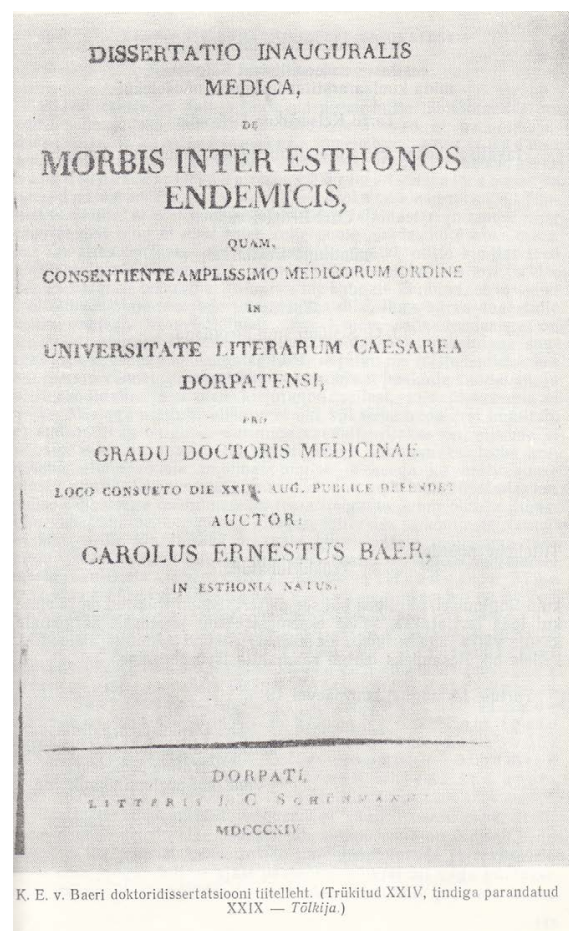

Figure 1. Title page of Karl Ernst v. Baer's doctoral theses. Dorpat (Tartu), 1814.

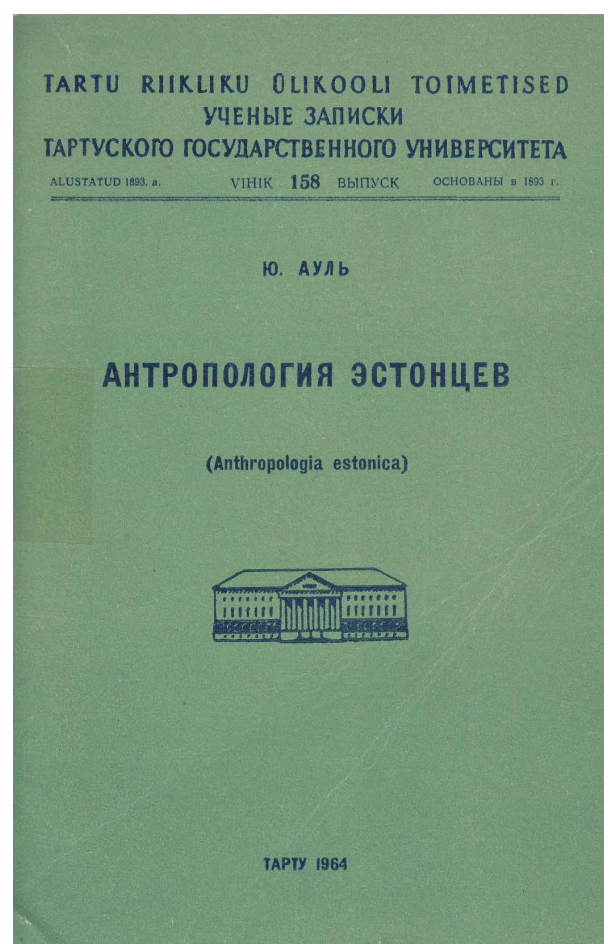

Figure 2. Cover of J. Aul's monograph Антропология эстонцев (Anthropologia estonica), (Estonians' Anthropology). Tartu, 1964.

Because of the coincidence of several unfavourable circumstances, J. Aul needed more than 30 years for writing this monograph, starting from data collection all over Estonia to the publication of the book. However, he had an excellent opportunity to present his monograph at the 7th International Congress of Anthropology and Ethnography in Moscow in August 1964.

Before that, J. Aul had also laid the foundation to the series Antropoloogiaalaseid töid (Papers on Anthropology) (Figure 3), the first issue of which was also published in July 1964 [1]. It became the predecessor of the current Papers on Anthropology, which enables us to celebrate the 50th anniversary of the publication of the first issue of the series.

Next, we will provide a longer overview of this Congress in Moscow; one of the Estonian scholars participating in it was also Prof. J. Aul. 
By that time, anthropological research in the whole of what was then the Soviet Union had made noticeable progress, particularly in the last few years [16].

The 7th International Congress of Anthropology and Ethnography was held in Moscow from 3-10 August 1964.

Fifty-eight countries with a total of 1940 delegates were represented at the Congress; in addition, numerous interested persons participated as guests.

In its number of participants, the 7 th Congress surpassed all the earlier ones. At the previous, 6th Congress in Paris there had been approximately 1200 delegates.

Such congresses had their beginning in London in 1934, where

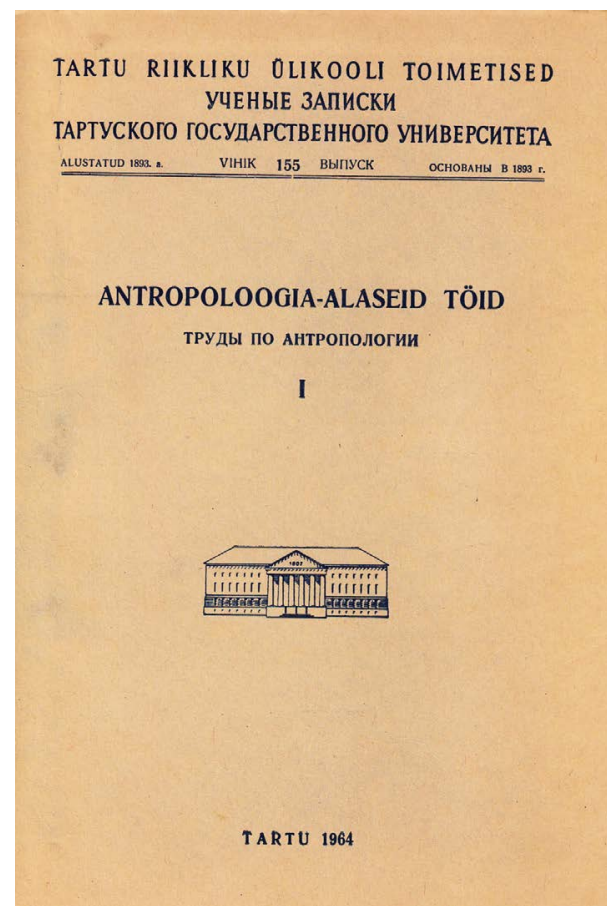

Figure 3. Cover of Antropoloogia-alaseid töid I (Труды по антропологии I - Papers on Anthropology I). Tartu, 1964. almost 150 delegates participated in the 1st International Congress of Anthropology and Ethnology (Ethnography). The 2nd Congress was held in Copenhagen in 1938, the 3rd in Brussels in 1948, the 4th in Vienna in 1952 and the 5th in Philadelphia in 1956; the number of participants increased constantly.

In addition to anthropologists and ethnographers, the participants of the Moscow Congress included renowned scholars from neighbouring specialities (linguists, philosophers, geographers, biologists, literary scholars, art theorists, historians).

A great number of scholars of international renown were present, like the anthropologist M. Gerasimov from the then Soviet Union, the well-known explorer Dr. Thor Heyerdahl from Norway, President of the International Union of Anthropology and Ethnography, Prof. H. Vallois from France, etc.

Researchers from African, Asian and Latin American countries were represented in greater numbers than at earlier congresses. 
The programme of the Congress was extensive. During eight days, presentations were made in 27 sections; discussions were held at 17 symposiums; several methodological boards were working; two plenary sessions were held.

At the plenary session of 5 August, Prof. P. C. Biswas (India) spoke on the theme "Present-day situation of racial and caste relations in India". At the plenary session of 8 August, the participants listened to Prof. H. Gandev's (Bulgaria) presentation "On progress in the studies of present-day life in European socialist countries”.

The work of five sections and three subsections and three symposiums at the 7th Congress was devoted to the problems of anthropology.

The anthropological sections of the Congress were:

1. physiological anthropology (head V. V. Bunak), subsection: haematology and serology.

2. Human somatology (head V. V. Ginzburg), subsections: (a) sports anthropology, (b) dermatoglyphics.

3. Anatomical anthropology (head D. A. Zhdanov).

4. Ethnic anthropology (head T. A. Trofimova).

5. Paleoanthropology and anthropogenesis (head V. P. Yakimov).

The anthropological symposiums of the Congress were:

1. Methods of anthropological analysis, formative factors of racial characteristics and principles of classification of races (head V. P. Alekseyev).

2. Systematics and nomenclature of the form of excavated hominids (head E. Vltšek, the then Czechoslovak Socialist Republic).

3. Problem of the border between the animal and the human (head V. P. Yakimov).

More than 240 presentations were made at the 44 sessions of anthropological sections and subsections.

In addition to purely anthropological and ethnographical sections, interesting sections with a general theoretical slant had been organised which were of interest to representatives of several specialities, like the section of theory and methodology and social order, and sections bordering on other specialities (ethnobotany and ethnozoology, ethnolinguistics and ethnic geography).

The phenomena of people's spiritual culture were discussed in the sections of oral folklore, folk music and choreography, religion and mythology. 
Anthropological and ethnographic problems of certain geographic regions had been concentrated into corresponding sections. Thus, there were the sections of Africa, North America, Europe, Australia and Oceania, etc.

A total of 812 presentations were made in all the sections of the Congress; 300 of them by Soviet scholars.

Simultaneously with sections and symposiums, films (80 in total) were shown on the life and customs, folk art, etc. of several peoples.

Numerous participants attended the symposium on the last days of the Congress where Morgan's theory of periodisation of primeval society was discussed [18].

The then Estonian SSR was represented by 27 delegates and 7 guests at the 7th International Congress of Anthropology and Ethnography in Moscow.

The delegation included anthropologists, ethnographers, archaeologists, historians and folklorists from Tartu State University, Institute of History, Institute of Language and Literature, the Literary Museum, the Ethnographical Museum, the Estonian SSR Open-Air Museum, Pärnu Museum of Local History, the Composers Union of the Estonian SSR, and the Estonian Department of the USSR Music Foundation.

The delegation was headed by Harri Moora, Academician of the Academy of Sciences of the Estonian SSR.

Estonian scholars made 11 presentations at the Congress.

Among them, the presentations on anthropology were "On anthropometric features accompanying puberty" by Juhan Aul and "Anthropology of Volga and Permian Finns" by Karin Mark.

The ethnographical presentations were "Changes in Soviet Latvian and Soviet Estonian fishermen's techniques, culture and lifestyle" by L. Yefremova, E. Čivkule and Arved Luts, and "Popular foods in the Estonian village and the problem of rational nutrition” by Endla Lõoke-Jaagosild.

The ethnographical-museological presentations were "The organisational principles of the Estonian SSR Open-Air Museum” by Olympi Korzyukov, "On experience of the Estonian SSR Ethnographical Museum in storing ethnographical items" by Jüri Linnus and "On collection of materials on building at the Estonian SSR Ethnographical Museum from 1959-1963” by Aleksei Peterson.

Presentations on folklore and folk music included "Stylistic types of Estonian folk tunes" by Herbert Tampere and "On the production magic function of folk stories" by Richard Viidalepp. 
Academician H. Moora's presentation "On the emergence of the historical cultural region of the Baltic countries" and Ants Viires' presentation "On historical and cultural relations of agricultural transport between the Baltic peoples" viewed more general historical and cultural relations between the peoples of the Baltic countries.

The Estonian scholars also took several pertinent publications to the Congress:

Aliise Moora, "On the ethnic history of the Peipsi region", 368 pp., in Estonian, summaries in Russian and German [8].

A German-language book on Estonian folk culture "Abriss der estnischen Volkskunde", $308 \mathrm{pp}$ [14]. This overview produced as teamwork had been translated into German by Salme Kirotar from Tartu. Before publication, H. Moora sent the translation to Berlin, to an acquaintance of his, Professor Wolfgang Steinitz, with a request to have it reviewed at the small German Institute of Social Science headed by him. Very few corrections were made. The book became an impressive publication on paper of very good quality for that time. Because of its linguistic accessibility, the book was a great success at the Congress; 140 copies were sold [9].

This showed that even then it was most necessary to publish some books introducing Estonia in Western European languages, not to mention the necessity for summaries in foreign languages [8].

J. Aul, however, presented several of his published works to the 7th Congress of Anthropology and Ethnography in Moscow in 1964:

1. Anthropology of Estonians, Issue 158 of the Transactions of Tartu State University (established in 1893), 387 pp., in Russian, summaries in Estonian and German.

2. The collection Papers on Anthropology I, Issue 155 of the Transactions of Tartu State University on 165 pages. It included two articles by him in Estonian ("Data for anthropological studies of Latvians" and "On some features of physical development of Estonian school students") with summaries in Russian and German, and two of his articles in Russian ("On the anthropology of Russians of the eastern region of the Estonian SSR" and "Anthropological studies of Votians and Izhorians in the western part of Leningrad region") with summaries in Estonian and German [1,7].

In the current article, we pay somewhat greater attention to J. Aul and the above-mentioned papers because of their significance in the history of Estonian anthropology. 
Before proceeding to that, however, let us mention the three Estonian films shown at the Congress: "Winter seine-fishing on Pärnu Bay" by the Estonian SSR Ethnographical Museum (filmed under the supervision of A. Luts), "Kihnu wedding" by Tartu State University (filmed under the supervision of E. Laugaste) and the colour documentary "Beauty around us" by the Tallinn Film Studio [7].

Having introduced the presentations, monographs and collections as well as films presented to the Moscow Congress by Estonian scholars, we can say that some of them were less time-consuming, for some others, however, relatively much time was needed from the beginning of data collection to publishing of research results, as usual for anthropological studies.

In the column "About everything for everyone" (Kõigest kõigile) published in Issue 7 of the newspaper Edasi in Tartu on 10 January 1964, we find a news item on Estonians' Anthropology where the author of the monograph, J. Aul himself, speaks about it. We present it here.

"Professor J. Aul, Head of the Department of Zoology at Tartu State University, has been studying Estonians' anthropology for a long time. Now his study has been completed. Most probably, it will be published in print before the International Congress of Ethnographers and Anthropologists, which will be held in Moscow in August this year.

When talking to the scientist, the reporter inquired about some details. When did you begin your research, what did you pay attention to?

"I began to compile the monograph in 1934; anthropometric measurements were taken from 15,000 male persons. The study observes 40 anthropological characteristics. For example, one of the essential features is the mean height. In Estonians, it reaches 172 centimetres. The tallest men live on Muhu Island and the western coast. The mean weight in $69.7 \mathrm{~kg}$.

The monograph also describes racial features. One of the most essential is hair colour. Eight per cent of men are dark-haired; the percentage of brownhaired is $19 \%$. Brown-eyed men constitute $6.6 \%$ of the total. Blue and grey eyes predominate.

Dark hair and brown eyes are not characteristic of Estonians. These racial features originate from somewhere in the south. The spread of foreign racial features can be caused, for example, by the settlement of Poles in Estonia in the 17 th century. Legends say that Spanish seamen rescued from shipwreck have settled on Saaremaa Island and on the western coast. These are opinions; the origin of foreign racial features still needs clarification. Historians also have to express their opinion here. 
The monograph gives an overview of Estonian men's physical development from 1930-1940. As there are no comparative data, no parallels with the past can be drawn. It would be interesting, for example, to know what Estonians were like at the beginning of the past century. When anthropometric measurements are arranged again in the future, comparisons and conclusions can be drawn on a larger scale.

We have to know the anthropology of our people. This is particularly necessary for physical education teachers, paediatricians and lawyers in their professional work.

The data published in the monograph might also be of interest for industrial enterprises. Based on them, footwear and clothing factories can compile scales of sizes acceptable for us." [4].

Issue 165 of the newspaper Edasi, published on 8 August 1964, i.e. during the Moscow Congress, published E. Tulem's article "From our scientists" (Meie teadlastelt).

As the article shows, the international scientific forum was also connected with our hometown Tartu in another way. So that the delegates of Tartu could leave for the Congress with bulky luggage, a contribution was made by Hans Heidemann printing shop. Two solid studies became good-looking books just before the Congress: A. Moora's historical-ethnographical study on EstonianRussian relations in the settlement and economy in the region of Lake Peipsi and J. Aul's monograph on the anthropology of Estonian men; in addition to them the first issue of a collection of articles on anthropology was published.

About Estonians' Anthropology, E. Tulem writes in the article that the researcher from Tartu began collecting his extensive material in 1932; he studied and measured more than 15,000 Estonian men. J. Aul needed as much as 32 years for assembling his highly valuable research material into a monograph.

The article shows that J. Aul's measurements and observations lead to the conclusion that Estonians are one of the peoples with the lightest hair and eyes. There are respectively $73 \%$ and $89.3 \%$ of them among the persons measured. The residents of the islands (excluding Muhu), the West Estonian coastal areas and Central Estonia are more dark-haired. In towns, the share of dark-haired people is greater. Estonians can be considered tall, strong and corpulent. In general, townspeople have weaker body build, but they are more gracile. Estonians are a mixed people where the Western and Eastern Baltic races predominate [8]. Here we should add that, in our opinion, nearly everything written in the article concerns Estonian men, as J. Aul had studied only males in his anthropological 
study. In order to speak about the anthropology of Estonians, females and children should also have been anthropologically studied in addition to males.

Perhaps the author of the article, when reading J. Aul's monograph published in Russian under the title Антропология эстонцев, did not realise that the Russian word эстонец was used for male Estonians only. In the title of the monograph, the Russian word appears in the genitive case plural (эстонцев), the Estonian for which is eestlaste, although here it includes only male Estonians. The word used for female Estonians in Russian is эстонка, which would be eestlanna in Estonian.

The typesetting of the monograph on Estonian men's anthropology, Антропология эстонцев (Anthropologia estonica) began on 20 May 1964; its printing started on 7 July 1964, and 500 copies were printed. The members of the editorial board were H. Remm (editor in charge), J. Aul and J. Ristkok. The proofreaders were A. Pravdin, A. Norberg and F. Kibbermann [16].

Before that, J. Aul had also prepared for print the collection Antropoloogiaalaseid töid I (Труды по антропологии I - Papers on Anthropology I), the typesetting of which began on 2 December 1963; its printing started on 18 July 1964, and 500 copies were printed. The editorial board was J. Ristkok (editor in charge), J. Aul and H. Remm. The proofreaders were E. Võhandu, A. Pravdin and F. Kibbermann. The dust jacket was designed by H. Pilter [1].

Here, the question might arise why J. Aul did not call his monograph the second collection of the series Papers on Anthropology or did not start the series with it.

No one before him or afterwards is known to have carried out so thorough anthropological research on the men of his nation. The subjects' age was mostly 21-22 years; they originated from all the 11 counties of the then Republic of Estonia [6]. The percentage of subjects from the total number of men in the counties varied between 2.87 and 4.85 (the percentage was the lowest in Järvamaa County and the highest in Saaremaa County). For their anthropological characterisation, 64 characteristics and indices were used [16].

However, in 1920-1922 G. Backman is known to have measured 11,415 soldiers in Latvia, recording their mean height [17].

Nearly ten years passed before Issue 330 of the Transactions of Tartu State University, Papers on Anthropology II (Antropoloogia-alaseid töid II, Труды по антропологии II) was published. Its typesetting started on 29 June 1973 and printing on 19 June 1974; 400 copies were made at Hans Heidemann printing 
shop. The editorial board was J. Aul, H. Ling, H. Remm (editor in charge). The proofreaders were A. Norberg, N. Chikalova, E. Kaldjärv and R. Veskimets. On the 90 pages of the collection, J. Aul published two articles - "On the anthropology of Northwestern Russian women" (in Russian, summaries in Estonian and German) and "On the anthropology of Estonian Germans" (in German, summaries in Estonian and Russian). L. Heapost published an article in Estonian "On the labour capacity of school students of Tallinn" (summaries in Russian and English). The article in Estonian by A. Horn, who had deceased by that time, was entitled "On the frequency of the main types of fingerprint patterns in Estonians" (summaries in Russian and German) [2].

The next collection of the series was published three years later as Issue 438 of the Transactions of Tartu State University with the title Antropoloogia-alaseid töid III (Труды по антропологии III - Papers on Anthropology III). Analysis of Estonians' anthropological data. The collection was dedicated to Prof. J. Aul's 80th birthday; its typesetting began on 27 April 1977 and printing on 9 November 1977. Hans Heidemann printing shop printed 500 copies of it.

The editor in charge was K. Põldvere, the proofreaders V. Lang, V. Loginova, S. Talts. On the 133 pages of the collection, J. Aul published one article in Estonian - "Estonian women's anthropology" (summaries in Russian and German). L. Heapost published two articles - "Some data on Ugric peoples' serology" (in Russian, summaries in Estonian and English) and "Facial measurements of school students of Tallinn" (in Estonian, summaries in Russian and English) [3].

More than ten years passed before the following collection of the series was published as Issue 816 of the Transactions of Tartu State University. Its title was Труды по антропологии IV. Актуальные вопросы антропологии (in Estonian: Antropoloogia-alaseid töid IV. Antropoloogia aktuaalseid küsimusi. Papers on Anthropology IV. Topical Problems of Anthropology). The collection was dedicated to Prof. J. Aul's 90th birthday; it contained 148 pages in Russian and its printing started on 5 May 1988. Tartu State University printing shop printed 400 copies of it. The editorial board was H. Kaarma (editor in charge), L. Saluste, E. Lepp, G. Jagomägi. The 23 articles in the collection were written by 7 scholars from Tartu, 2 from Tallinn, 4 from Vilnius, 1 from Kaunas, 7 from Minsk, 1 from Leningrad (now St Petersburg) and 1 from Moscow [15].

In the 1980s, several changes took place in Estonian education and research. On 30 September 1988, the university council adopted new statutes, according to which the name of the university was changed into the University of Tartu. The University of Tartu became the national university of Estonia. The Transactions 
of Tartu State University were renamed the Transactions of the University of Tartu.

The publication of Papers on Anthropology continued, now with the title in English, but the serial numbers of the series that had its beginning in 1964 with its old name Antropoloogia-alaseid töid did not change.

Issue 951 of Transactions of the University of Tartu, Papers on Anthropology V (Figure 4) was published in English on 130 pages in 1992, thus after the restoration of Estonia's independence. The collection was dedicated to the $95^{\text {th }}$ birthday of Prof. Juhan Aul. University of Tartu Press printed 250 copies of it.

The editor in charge was H. Kaarma. The collection included 18 articles -12 by scholars from Tartu, 2 from Tallinn, 3 from Vilnius and 1 from Minsk [10].

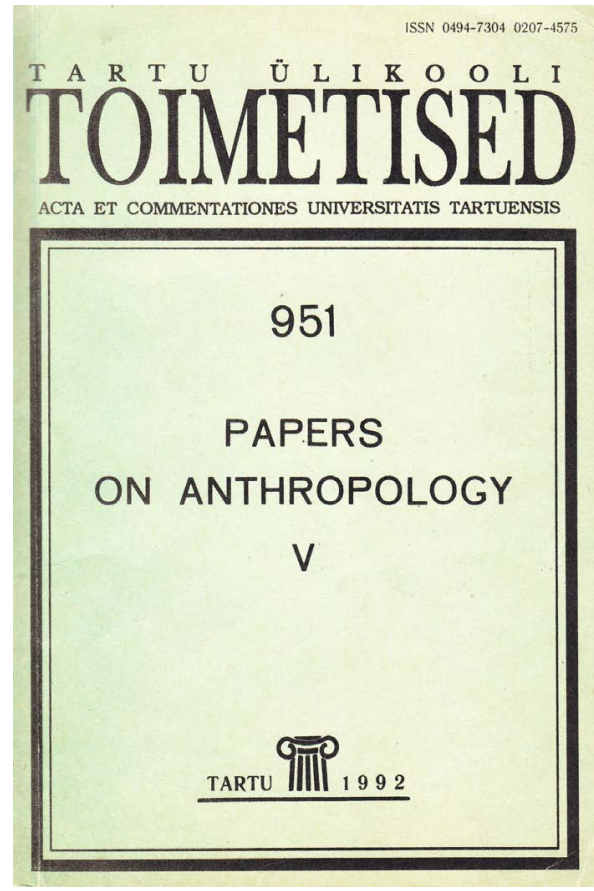

Figure 4. Cover of Papers on Anthropology V. Tartu, 1992.

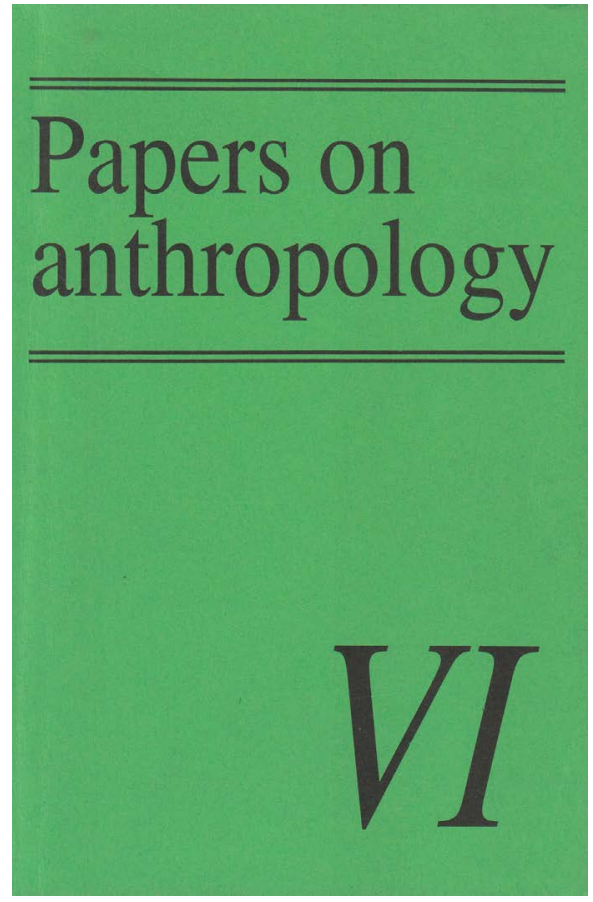

Figure 5. Cover of Papers on Anthropology VI. Tartu, 1995.

The publication and development of the collection Papers on Anthropology has continued to the present time (Figure 4, 5, 6); from its 5th issue, the editor has been Prof. H. Kaarma. Last year, in October 2013, the 22nd issue of the collection was published. 
This year a great change happened in the publication of the collection; two issues are published. Therefore, from this year onwards, we might speak about the journal rather than the collection Papers on Anthropology; one volume is published each year with sequentially numbered issues within it. Thus, in 2014, Issue 1 of Volume 23 of the journal Papers on Anthropology (Figure 7) has already been published on 151 pages, printed at University of Tartu Press. Its editor is Helje Kaarma MD.

The international editorial board includes Leiu Heapost $\mathrm{PhD}$ (Estonia), Prof. Barbara Hulanicka (Poland), Prof. Rimantas Jankauskas (Lithuania), Prof. Toivo Jürimäe (Estonia), Prof. Antonia Marcsik (Hungary), Prof. Miroslav Prokopec (the Czech Republic), Prof. Esther Rebato (Spain), Prof. Romuald Stupnicki (Poland), Prof. Charles Susanne (Belgium) and Prof. Ene-Margit Tiit (Estonia).

The journal is indexed in BIOSIS, SPORTDiscus, Anthropological Index Online, EBSCO Publishing, CABI International, Index Copernicus International, Thomson Scientific Master Journal List.

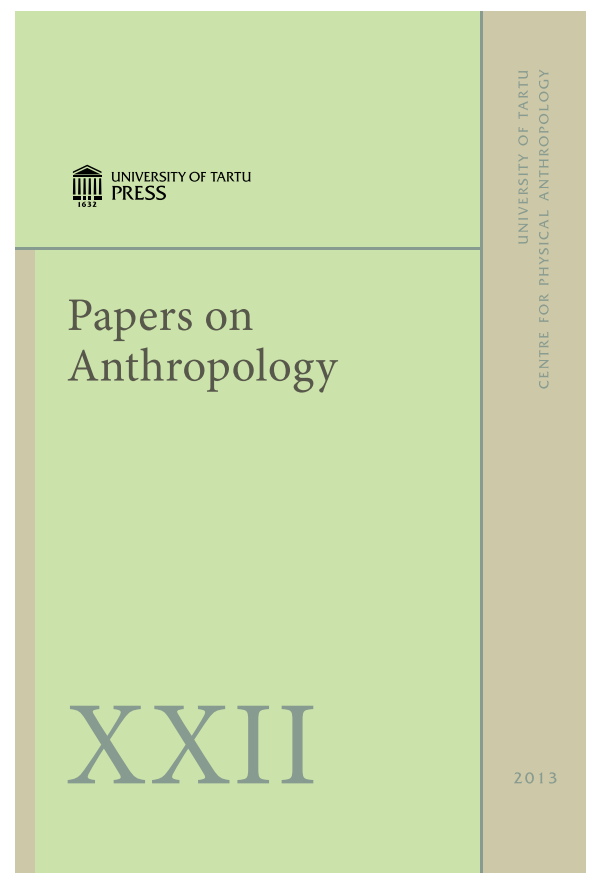

Figure 6. Cover of Papers on Anthropology XXII. Tartu, 2013.

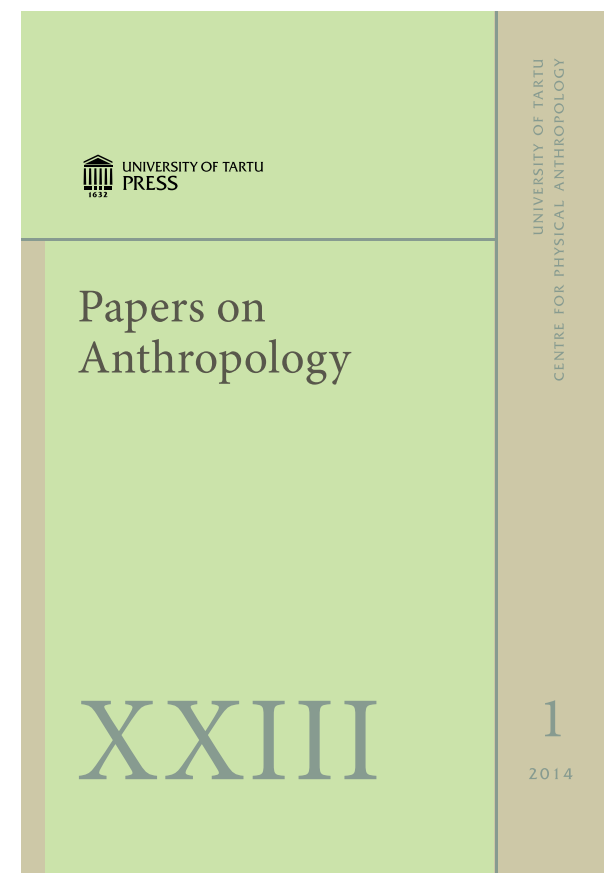

Figure 7. Cover of Papers on Anthropology XXIII, 1. Tartu, 2014. 
The authors and co-authors of the 12 articles published in this issue are from the United Kingdom, the United States, Germany, Austria, Greece, Lithuania and South Korea.

The publication of the journal is supported by the Institute of Anatomy (head Prof. A. Arend) of the University of Tartu.

The journal is available electronically at http:// ojs.utlib.ee/index.php/PoA [13].

You were reading an overview of the events 50 years ago in the history of Estonian anthropology on the pages of Issue 2 of Volume 23 of the newly published journal Papers on Anthropology.

Another reason why the current year is special is that the anthropological research of Estonians had its beginning in 1814, i.e. 200 years ago.

\section{REFERENCES}

1. Antropoloogia-alaseid töid I. Труды по антропологии I. (1964). Tartu Riikliku Ülikooli Toimetised. Vihik 155. Tartu.

2. Antropoloogia-alaseid töid II. Труды по антропологии II. (1974). Tartu Riikliku Ülikooli Toimetised. Vihik 330. Тарту.

3. Antropoloogia-alaseid töid III. Труды по антропологии III. (1977). Eestlaste antropoloogiliste andmete analüüs. Tartu Riikliku Ülikooli Toimetised. Vihik 438. Tartu.

4. Eestlaste antropoloogia. (1964). Edasi, nr. 7, 10. jaanuaril.

5. Ilomets T. (1975). Karl Ernst v. Baeri doktoritöö kaitsmisest. In: Folia Baeriana I. Tallinn, Valgus, 110-142.

6. Maakond. (1938). In: Väike entsüklopeedia. Tartu-Tallinn, Loodus, 943.

7. Muljeid VII rahvusvaheliselt antropoloogia ja etnograafia kongressilt. (1964). Keel ja Kirjandus, 11, 697-698.

8. Tulem E. (1964). Meie teadlastelt. Edasi, nr. 156, 8. augustil.

9. Viires A. (2007). Rännud aastail 1957-1966. Tuna, 2, 72-86.

10. Papers on Anthropology V. (1992). Tartu Ülikooli Toimetised. Vihik 951. Tartu.

11. Papers on Anthropology VI (1995). Tartu.

12. Papers on anthropology XXII (2013). Tartu.

13. Papers on Anthropology XXIII/1. Tartu, 2014.

14. Abriss der estnischen Volkskunde. (1964). Tallinn.

15. Актуальные вопросы антропологии. Труды по антропологии IV. (1988). Tartu Riikliku Ülikooli Toimetised. Vihik 816. Тарту. 
16. Ауль Ю. (1964). Антропология эстонцев. (Anthropologia estonica). Tartu Riikliku Ülikooli Toimetised. Vihik 158. Тарту.

17. Герке П. Я. (1979). К истории антропологических исследований в Латвии. In: Из истории медицины. Сборник статей XI. Рига, 64-72.

18. Международные встречи антропологов в Москве. (1965). Вопросы антропологии, 19, 3-7.

\section{Address for correspondence:}

Jaan Kasmel

Centre for Physical Anthropology

Struve 2, 51003, Tartu, Estonia

E-mail: jaanjkasmel@hot.ee 